Original Research

\title{
Dust Generation and Respiratory Impact of Underground Coal-Producing Mines in Pakistan
}

\author{
Madiha Ijaz', Muhammad Akram', Sajid Rashid Ahmad', Waheed Ullah Khan'*, \\ Steven M. Thygerson ${ }^{2}$, Falaq Ali Nadeem ${ }^{3}$ \\ ${ }^{1}$ College of Earth and Environmental Sciences, New Campus, University of the Punjab, Lahore, Pakistan \\ ${ }^{2}$ Department of Public Health, College of Life Sciences, Brigham Young University, UT, USA \\ ${ }^{3}$ College of Statistical and Actuarial Sciences, University of the Punjab, Lahore, Pakistan
}

Received: 25 October 2019

Accepted: 15 December 2019

\begin{abstract}
Coal is a major source of energy in developing countries. Its underground mining exposes workers to respirable dust containing silica, causing respiratory illness. The objectives of this study include measuring this dust and the percentage of its silica content and evaluating the prevalence of respiratory diseases among coal cutters. A walkthrough survey performa, SKC Airchek 52 (SKC Inc., eighty four, PA, USA) air sampling pumps, an anemometer, hygrometer, multi-gas detector, a thermometer and modified International Union Against Tuberculosis and Lung Disease (IUATLD) respiratory questionnaire were used to collect data from 64 workers working in 5 different mines of Chakwal District in Punjab, Pakistan. Mine E, with the lowest ventilation volumetric flow rate $\left(18 \mathrm{~m}^{3} / \mathrm{s}\right)$, has the highest dust concentration $\left(6.10 \mathrm{mg} / \mathrm{m}^{3}\right.$, silica content $\left.2.699 \%\right)$. Conversely, mine A, with the highest ventilation volumetric flow rate $\left(45 \mathrm{~m}^{3} / \mathrm{s}\right)$, has the lowest dust concentration $\left(2.58 \mathrm{mg} / \mathrm{m}^{3}, 1.33 \%\right.$ silica content). Survey results show that $71 \%$ of workers inherited this occupation, $94 \%$ did not smoke, $99 \%$ did not use any dust mask, 47\% have diagnosed tuberculosis and 8\% asthma. About 57, 48, 44 and 42 workers reported cough, phlegm, chest tightness and shortness of breath, respectively. The $89 \%$ workers were told by their physicians that dust exposure was the reason for their respiratory ailment.
\end{abstract}

Keywords: asthma, coal mines, coal cutters, forced ventilation, respirable dust, respiratory diseases, silica content, tuberculosis

*e-mail: waheedenviro@gmail.com 


\section{Introduction}

In many countries, especially developing ones, energy production from coal is still a rising trend [1-2]. There are two coal mining methods: underground and open cast [3]. Underground coal mining becomes dangerous for workers' health as it generates dust which harms workers' respiratory tracts [4]. Many efforts like dust suppression, forced ventilation and legislation have been introduced in coal mines in hopes of reducing respiratory diseases [5]. Previous research developed the relationship between air velocity and quantity to the concentration of dust particles, thus reducing the level of inhalable dust. However, inhalation hazards in the mines still persist throughout the world [6]. The dust concentration in underground coal mines of developing countries is worse compared to that of developed countries [7]. Likewise, there is a high prevalence of respirable dust in coal mines of Pakistan because coal mining is mostly underground and practiced manually.

To evaluate the health impacts of dust in underground coal mines, it is significant to understand its mineralogy and composition. Its inorganic (mineral) composition comprising of silica, phyllosilicate, carbonates and sulphides [8] and organic (macerals) components produce a broad spectrum of metallic elements that damage lungs when inhaled [9]. Worker exposure to this dust causes coal mine dust lung disease (CMDLD), coal workers pneumoconiosis (CWP) or progressive massive fibrosis (PMF) [10]. Coal and silica dust together can produce mixed dust pneumoconiosis. Workers who already have rheumatoid arthritis in addition to pneumoconiosis become highly vulnerable to rheumatoid pneumoconiosis, which is also called Caplan syndrome [11].

Workers exposed to respirable dust is the root cause of workers' respiratory diseases. The quality of air near an active coal mining face plays a significant role for workers' exposure to dust [12]. Dust concentration has a strong relationship with ventilation and air flow rate controlled by a curtain system [13]. Silica content in different percentages in respirable dust disturbs workers' lungs [14]. For this reason, the National Institute for Occupational Safety and Health (NIOSH) in the United States has prescribed different occupational exposure limits for dust with $>5 \%$ and $<5 \%$ silica content [15].

The aims of the current study are:

- To find concentrations of inhalable dust and the percentage of its silica content in underground coal mines.

- To check levels of significance of this inhalable dust for respiratory diseases .

- To collect data of prevailing respiratory disorders in workers (coal cutters) of underground coal mines.

- To suggest remedial measure for workers' exposure to this respirable dust.

\section{Material and Methods}

\section{Walkthrough Survey}

A walkthrough survey was conducted using a validated survey tool [16-17]. During this survey some data, described in Table 1, was obtained about the mines to be included in the study. After describing the aims of the study, workers at each site were asked to give consent to be part of the study. They were also guided, in advance, about how to complete the respiratory questionnaire.

During the study, coal excavation rates did not exceed 20 tons/day. However, average coal production of the Chakwal district is 25 tons/day. Bituminous or sub-bituminous is the only type of coal mined in the study area. The forced ventilation system is comprised of small exhaust fans used to supply air in tunnels where work is being done. Air curtains were used to divert the movement of air in these mines.

\section{Possibility of Airborne Pathogens and Our Limitations}

Donkeys were used to transport excavated coal at the dumping site. Airborne pathogens in underground coal mines have been observed in many studies [18-

Table 1. Characteristics of the mines under study.

\begin{tabular}{|c|c|c|c|c|c|}
\hline Features & Mine A & Mine B & Mine C & Mine D & Mine E \\
\hline Host rock of the seam & Patala formation & Patala formation & Patala formation & Patala formation & Patala formation \\
\hline Thickness of coal seam & 2 & 3 & 2.5 & 3 & 2.5 \\
\hline Type of coal & Bituminous & Bituminous & Sub-bituminous & Bituminous & Bituminous \\
\hline $\begin{array}{c}\text { Number of active faces } \\
\begin{array}{c}\text { Coal production/day (from all } \\
\text { faces) }\end{array}\end{array}$ & 6 & 5 & 5 & 6 & 17 tons \\
\hline $\begin{array}{c}\text { Number of coal cutters on all } \\
\text { faces }\end{array}$ & 13.5 tons & 18 tons & 16 & 15 & 14 \\
\hline Ventilation system & Forced ventilation & Natural & Natural & Forced ventilation & Natural \\
\hline
\end{tabular}


19]. Donkey urine and dung is not cleaned and left for natural decay. Not only does this create a foul odor but also the microbial concentration increases to trigger biological diseases. Leftover food from workers' lunches also attracts rats that come to feed on this food. In a poorly ventilated but highly humid environment, workers are exposed to pathogens from these sources. Pictures 2.1 and 2.2 show the use of donkeys.

\section{Study Area and Sampling of Workers}

The months of sampling were February-March 2019. Five mines (coded as A, B, C, D and E) were selected for study in Chakwal District. A total of 64 coal-cutting workers were selected for the study and prior oral consent was sought from workers. No workers under 25 years of age and with less than 5 years of coalcutting experience were included in the study.

\section{Measurement and Analysis of Inhalable Dust}

NIOSH method 7500 was followed to carry out air sampling [20]. Breathing zone samples were collected using an SKC Aircheck 52 (SKC Inc., eighty four, PA, USA) [21]. Personal air sampling pumps having preweighed $5.0 \mathrm{~mm}$ PVC membrane filters $(37 \mathrm{~mm})$ and an in-line aluminum cyclone with a $4.0-\mathrm{mm}$ cut point to separate particulates in advance. The flow rate was adjusted at $2.5 \mathrm{~L} / \mathrm{min}$ and we performed pre- and post-calibration with the help of a DryCal Defender 510 primary volumetric flow standard (Mesa Labs, Butler, NJ, USA) to ensure its consistency. Sample filters along with field and laboratory blanks were analyzed in detail gravimetrically and by X-ray diffraction (XRD) [22].

\section{Sampling Time and Its Conversion to Time-Weighted Average (TWA)}

The traditional working time of mine workers is 10 hours/day, but we fixed the average at four hours and converted it to eight-hour time-weighted averages (TWA) using the following formula:

$$
\text { TWA }=\left[\left(\mathrm{C}_{1} \times \mathrm{T}_{1}\right)+\left(\mathrm{C}_{2} \times \mathrm{T}_{2}\right)+\left(\mathrm{C}_{\mathrm{n}} \times \mathrm{T}_{\mathrm{n}}\right)\right] / 480 \mathrm{~min}
$$

...where $\mathrm{C}=$ concentration for $\mathrm{T}_{\mathrm{n}}\left(\mu \mathrm{g} / \mathrm{m}^{3}\right)$ and $\mathrm{T}=$ sampling time (min). To put the value for $\mathrm{C}_{2}$ and $\mathrm{T}_{2}$ in formula we used the same concentration as $\mathrm{C}_{1}$ and the remainder of the shift, which was not sampled (6 hours) [23].

\section{Administered Respiratory Questionnaire}

A short form (translated to the local language of Urdu) of the International Union Against Tuberculosis and Lung Disease (IUATLD) was used to get the data on respiratory diseases among the study population. The important sections of the questionnaire included questions about existence, history, and frequency of attacks of respiratory diseases in different forms [24]. The prevalence of chronic bronchitis with and without phlegm was asked for $\geq 3$ months and for $>2$ years. The questions about environmental exposure and socio-demographic profile were also asked in separate sections. The validity and reliability of the IUATLD questionnaire has been checked and quoted in many research works [25].

\section{Use of Instruments to Measure Environmental Conditions of Mines}

We used an anemometer, hygrometer, multi-gas detector and a thermometer to measure air velocity, humidity, temperature, oxygen and $\mathrm{CO}$ level in the air surrounding the workers [26].

\section{Statistical Analysis}

Statistical analysis of prevailing levels of respirable dust and its silica content, the relationship between environmental factors (ventilation and air flow, etc.) and concentration of dust and data on self-reported respiratory diseases of workers was operated on SPSS, IBM, version 22 [27]. Multiple and component bar charts and graphs were drawn. Chi-square test of association was drawn to check the significance of physical and occupational factors over the prevalence of respiratory disease.

\section{Results and Discussion}

The present study is the first of its type measuring respirable dust with a percentage of silica content and respiratory issues of workers cutting coal in underground mines in Pakistan. Through comparative analysis, we delineated the role of different environmental and occupational factors in exposure to dust concentration and respiratory issues. However, in our study area the time of exposure is $>8$ hours with 9 months in a year on average. The rock type for all coal seams in this region was of the Patala formation [28]. All mines in this study used the long wall method for excavation of coal, and workers use the traditional equipment for it. Only 2 out of 5 mines used a forced exhaust system, which is not functional on a regular basis.

\section{Mean Characteristics of Workers}

Physical characteristics of workers were analyzed and means were calculated (Table 2). The average work-duration/day is nine hours. Coal miners work for 9.43 moths/year on average. These are calculated to understand average exposure time. No worker used safety masks to avoid dust exposure and only six workers reported that they cover their faces with cloth when they feel dusty air around. 
Table 2. Number of workers from every face of the mine.

\begin{tabular}{|c|c|c|c|c|}
\hline \multirow{2}{*}{ Sampling Location } & \multicolumn{2}{|c|}{ Number of sampled workers from each face } & \multirow{2}{*}{ Total number of samples } \\
\cline { 2 - 5 } & Face 1 & Face 2 & Face 3 & 13 \\
\hline Mine A & 4 & 5 & 4 & 12 \\
\hline Mine B & 4 & 4 & 5 & 13 \\
\hline Mine C & 3 & 5 & 3 & 15 \\
\hline Mine D & 4 & 4 & 4 & 11 \\
\hline Mine E & 4 & 3 & & \\
\hline
\end{tabular}

Among occupational factors, work experience (total number of working years), working months/year and working hours/day were found to be most significant, making workers exposed to the dust and causing respiratory diseases in them. It is obvious that workers who spend more time in the coal mine (with high dust concentration) will likely get more respiratory illnesses [29]. The NIOSH recommended time to spend at work is 8 hours/day, but in this study the workers were found to spend more than 10 hours/day, which increases their exposure to dust. The trend of respiratory disease is higher in workers with greater work experience [30]. On an annual basis, the workers spend at work a minimum of 8 months and maximum of 12 months without any weekly break. Other studies have also reported that workers get maximum exposure due to very short break times [31].

Fig. 1 describes several physical, demographic and respiratory symptoms reported by the workers. The majority of workers inherited the occupation
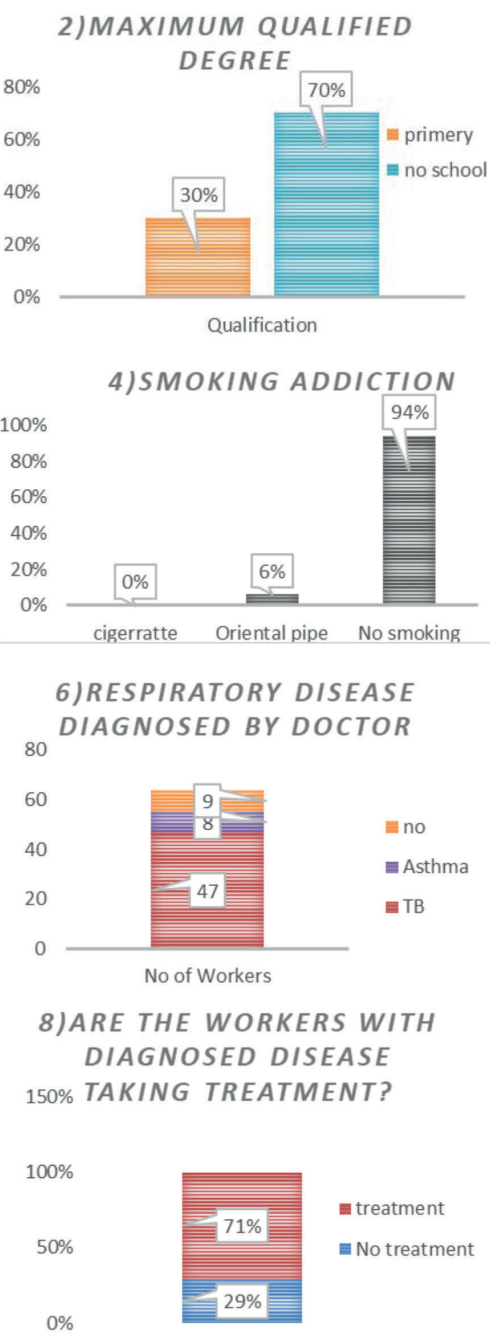

Fig. 1. Miscellaneous results obtained from workers. 
Table 3. Fundamental facts of workers.

\begin{tabular}{|c|c|c|c|c|}
\hline Name of characteristics & Mean & Standard deviation & Variance & Range \\
\hline Age (years) & 30.1719 & 5.162 & 26.653 & $4.11-6.1$ \\
\hline Height (feet) & 5.47 & 0.29 & 0.086 & $45-64$ \\
\hline Weight $(\mathrm{kg})$ & 55.31 & 3.15 & 9.933 & $16.9-22.5$ \\
\hline BMI $\left(\mathrm{kg} / \mathrm{m}^{2}\right)$ & 20.06 & 1.22 & 1.508 & $9-13$ \\
\hline Working hours/day & 10.00 & 1.038 & 1.488 & $8-12$ \\
\hline Working months/year & 9.43 & 1.219 & 11.589 & $8-22$ \\
\hline Work experience (years) & 11.32 & 3.40 & & \\
\hline
\end{tabular}

of underground coal mining, meaning they are doing the same work as their fathers. A total of 41 workers reported that they have been diagnosed with tuberculosis and 14 with asthma, while 9 workers have reported that they don't have any disease diagnosed by a doctor. Among those with diagnosed disease, $71 \%$ were not getting proper treatment. All workers $(100 \%)$ come from other provinces, which have tribal settlements where smoking is not common. Therefore, $94 \%$ of workers in this study don't smoke. Rather, they chew an herb called Niswar.

The statistical analysis of the data shows that physical and occupational factors have a great significance for workers' exposure to dust and the consequent respiratory issues. The mean age of workers of underground coal mines is 40 years and $43.62 \pm 9.52$ [32]. Whereas the mean value of our sampled workers was 30.17 years. The role of this mean age is significant for respiratory issues. Workers are more prone to get infections in their late age as compared to the young ones [33-34]. The workers who reported diagnosed disease were of old age with years of experience of work at underground coal mines. All workers $(\mathrm{n}=64)$ were underweight. The mean value was $<23 \mathrm{~kg} / \mathrm{m}^{2}$ and according to recommendations of the World Health Organization (WHO), an Asian person is said to be overweight if $\mathrm{BMI}>23 \mathrm{~kg} / \mathrm{m}^{2}$ [35-36].

\section{Environmental Monitoring of Underground Coal Mines}

The environmental conditions (Table 4) were measured where personal dust sampling was done.
Mines A, B and D used compressors (blower fan) to supply fresh air to workers at the mine face, and the values of air flow at these mines are $2 \mathrm{~m} / \mathrm{s}, 1.5 \mathrm{~m} / \mathrm{s}$ and $1.8 \mathrm{~m} / \mathrm{s}$, respectively. Mines $\mathrm{C}$ and $\mathrm{E}$ lack any compressor, and the natural rate of air flow was $0.9 \mathrm{~m} / \mathrm{s}$ in each. Carbon monoxide (CO) and oxygen levels were also measured. Minimum value of $\mathrm{O}_{2}$ should be $19.5 \%$ [37]. At mines A, B and D it was $19.5 \%$, while at mines $\mathrm{C}$ and $\mathrm{E}$ it was 19\%. Elevated CO levels were detected in all studied mines.

The samples from mines having air compressors resulted in less concentration of respirable dust, whereas the samples from mines without any mechanical or natural ventilation system resulted in the highest value of dust concentration, showing strong association, though not statistically significant. Some other studies suggest that the air flow rate should be at optimum level [38]. The flow rate should be 10 to 20 times higher than $11.4 \mathrm{~m}^{3} / \mathrm{min}$ in order to ensure the availability of fresh air to all workers [39]. Work Safe British Columbia in Canada (2005) mandates the minimum air flow rate at $85 \mathrm{~m}^{3} / \mathrm{hr}$ or $1.4 \mathrm{~m}^{3} / \mathrm{min}$ for every worker working in a confined space. However, the recommended maximum value is $4 \mathrm{~m} / \mathrm{s}$ (with $0.3 \mathrm{~m} / \mathrm{s}$ as minimum value) for such a confined underground workplace.

This study shows that air quantity and dust concentration at the coal mine are inversely proportional. This is the reason some countries, having high coal production rates, apply foam technology, coal bed diffusion and ventilation as a main technique to control dust [40-41]. Ventilation is one of the basic, inexpensive and time-tested methods of dust control in underground coal mines [42]. Greater air quantity

Table 4. Atmospheric conditions at mines under study.

\begin{tabular}{|c|c|c|c|c|c|c|}
\hline Mine & Air velocity & Air quantity & Humidity & Temperature (degrees Celsius) & Oxygen level & CO level \\
\hline Mine A & $1.8 \mathrm{~m} / \mathrm{s}$ & $45 \mathrm{~m}^{3} / \mathrm{s}$ & $57 \%$ & 24 & $19.5 \%$ & 0 \\
\hline Mine B & $1.5 \mathrm{~m} / \mathrm{s}$ & $33 \mathrm{~m}^{3} / \mathrm{s}$ & $55 \%$ & 25 & $19.5 \%$ & 0 \\
\hline Mine C & $0.9 \mathrm{~m} / \mathrm{s}$ & $22 \mathrm{~m}^{3} / \mathrm{s}$ & $72 \%$ & 25 & $19 \%$ & 0 \\
\hline Mine D & $2.0 \mathrm{~m} / \mathrm{s}$ & $36 \mathrm{~m}^{3} / \mathrm{s}$ & $51 \%$ & 26 & $19.5 \%$ & 0 \\
\hline Mine E & $0.9 \mathrm{~m} / \mathrm{s}$ & $18 \mathrm{~m}^{3} / \mathrm{s}$ & $85 \%$ & 27 & $19 \%$ & 0 \\
\hline
\end{tabular}


Table 5. Level of dust with silica content being respired by coal cutters during work.

\begin{tabular}{|c|c|c|c|c|c|c|}
\hline $\begin{array}{c}\text { Name } \\
\text { of Mine }\end{array}$ & $\begin{array}{c}\text { Number } \\
\text { of samples }\end{array}$ & $\begin{array}{c}\text { Mean of dust concentration } \\
\left(\mathrm{mg} / \mathrm{m}^{3}\right)\end{array}$ & Variance & $\begin{array}{c}\text { Standard } \\
\text { deviation }\end{array}$ & Range & $\begin{array}{c}\text { Mean percentage } \\
\text { of Silica content }\end{array}$ \\
\hline Mine A & 13 & 2.58 & 0.493 & 0.702 & $1.40-3.90$ & 1.33 \\
\hline Mine B & 12 & 3.53 & 00.629 & 0.793 & $2.11-4.60$ & 2.62 \\
\hline Mine C & 15 & 5.14 & 0.984 & 0.974 & $3.50-6.47$ & 2.918 \\
\hline Mine D & 13 & 3.0315 & 0.781 & 0.884 & $1.11-4.10$ & 2.258 \\
\hline Mine E & 11 & 6.10 & 0.608 & 0.78 & $4.90-7.00$ & 2.699 \\
\hline
\end{tabular}

reduces the dust concentration and methane [43]. The proportion between air flow streamlines and respirable dust trace lines show that respirable dust is largely affected by the air drag force [44].

\section{Dust Concentration with Percent Silica Content and Its Relationship with Environmental Factors}

The maximum concentration $\left(6.10 \mathrm{mg} / \mathrm{m}^{3}\right)$ of dust was found in 11 samples from mine $\mathrm{E}$ (Table 5). The dust concentration at this mine ranged from $4.90 \mathrm{mg} / \mathrm{m}^{3}$ to $7.00 \mathrm{mg} / \mathrm{m}^{3}$. The lowest mean value of dust concentration is $2.58 \mathrm{mg} / \mathrm{m}^{3}$ from mine A. The percent silica content was highest in samples from mine $\mathrm{D}$, with a value of $2.918 \%$, while it was lowest (1.33\%) in samples of Mine A. Fig. 2 gives the graphical representation of silica content in respirable dust levels.

The relationship between quantity of air (volumetric flow rate) and concentration of air is shown in Fig. 3. Names of mines are given on the x-axis while frequencies of dust concentration and quantity of air are given on the y-axis. The relationship is inversely proportional. We see that when dust concentration is at its lowest level (i.e., $2.58 \mathrm{mg} / \mathrm{m}^{3}$ ) the volumetric flow rate is at its highest $\left(45 \mathrm{~m}^{3} / \mathrm{s}\right)$. The lowest volumetric flow rate in mine $\mathrm{E}$ was $18 \mathrm{~m}^{3} / \mathrm{s}$, but resulted in the highest dust concentration of $6.1 \mathrm{mg} / \mathrm{m}^{3}$.

In all air samples of personnel breathing zone of the studied population, dust concentration was higher

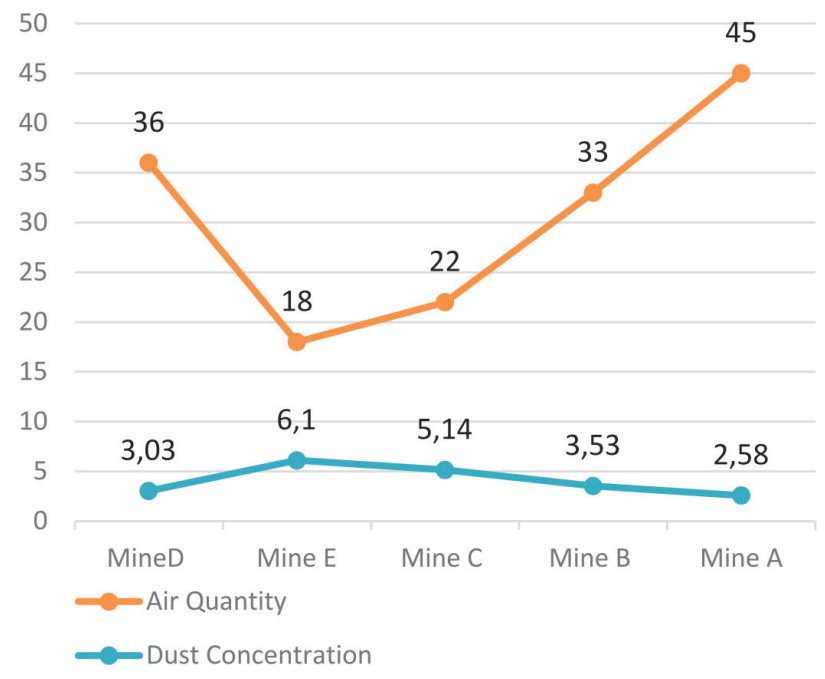

Fig. 3. Relationship between concentrations of respirable dust $\left(\mathrm{mg} / \mathrm{m}^{3}\right)$ and quantity of air $\left(\mathrm{m}^{3} / \mathrm{s}\right)$.

than the recommended values, whereas the percentage of silica was within permissible limits. The ACGIH TLV-TWA for respirable dust is $2 \mathrm{mg} / \mathrm{m}^{3}$ when silica content is $<5 \%$, but the value is reduced to $1 \mathrm{mg} / \mathrm{m}^{3}$ when silica content is $>5 \%$ (ACGIH 2019). PEL-TWA by US-OSHA is $0.1 \mathrm{mg} / \mathrm{m}^{3}$ for the respirable quartz fraction of coal dust having more than $5 \%$ quartz, whereas the limit is $2 \mathrm{mg} / \mathrm{m}^{3}$ if the percentage of quartz is less than 5\% (OSHA Standard 29 CFR 1910). The concentration

\section{Percentage of silica in samples of dust concentration}

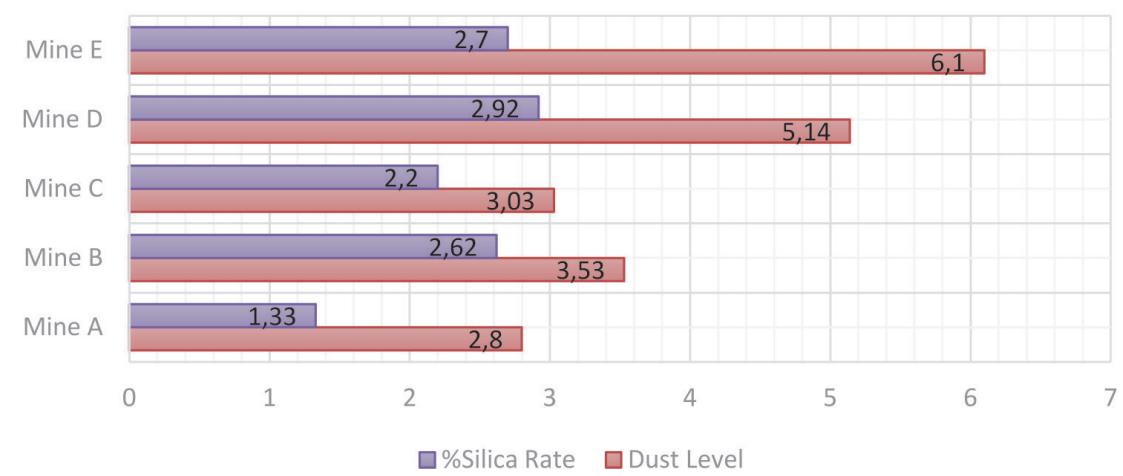

Fig. 2. Concentrations of respirable dust $\left(\mathrm{mg} / \mathrm{m}^{3}\right)$ and percentages of its silica content. 


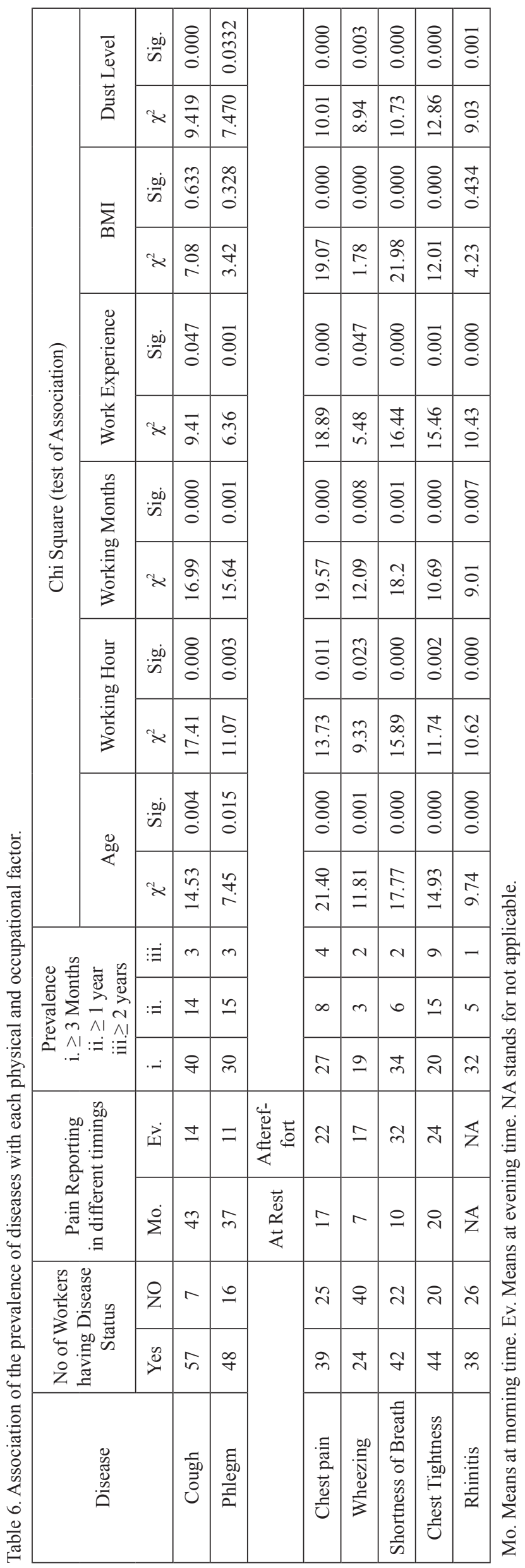

limits for respirable coal mine dust are $2.0 \mathrm{mg} / \mathrm{m}^{3}$ and $1.5 \mathrm{mg} / \mathrm{m}^{3}$ at underground and surface coal mines, respectively [45]. In this study, the concentration of inhalable dust was higher than the recommended limits of ACGIH and OSHA-US.

\section{Significance of Occupational and Physical Factors for Prevalence of Respiratory Issues Among Workers}

We performed the chi square test to check the significance of respirable dust concentrations for the prevalence of respiratory diseases. From the occupational and personal factors, we selected six parameters to check their significance for prevalence of respiratory disorders over $\geq 3$ months, $\geq 1$ year and $\geq 2$ years. The analysis is shown in Table 6 , which also shows the mean values of workers with Yes/No and morning/evening occurrence of respiratory issue.

Cough, phlegm and chest tightness were reported by a large number of workers. Cough was reported in $57 \%$ of workers, $48 \%$ of workers reported phlegm, and $44 \%$ reported chest tightness. Wheezing was the least reported respiratory disease, affecting only 24 workers. For morning and evening cough and phlegm, 43 out of 57 workers reported morning time and 14 reported in the evening. Morning phlegm was reported by 37 out of 48 workers while 11 reported evening phlegm.

Age is a significant factor for the prevalence of chest pain, shortness of breath, chest tightness and rhinitis ( $p$ value $=0.00)$. Age is also a significant factor for the prevalence of cough, phlegm and wheezing ( $\mathrm{p}$ value $=0.004,0.015$ and 0.001 , respectively). Working hours/day and working months/year were equally significant for the prevalence of cough. BMI is a significant physical factor for the prevalence of chest pain, chest tightness, wheezing and shortness of breath ( $p$ value $=0.000)$. However, BMI is not significant for cough $(\mathrm{p}$ value $=0.63)$.

The reporting of respiratory issues is interesting. Cough was almost common in all workers. The difference is only in cough with and without phlegm and its time of occurrence. The prevalence of cough and phlegm over different periods of time was also calculated. Tuberculosis was the commonly reported disease among diagnosed diseases and a lot of studies show that respirable coal dust is a significant reason behind tuberculosis [46-47]. Chest tightness and shortness of breath are found to be common among workers (who participated in this study) of underground coal mines, and the same conclusions are derived in other studies [48]. Rhinitis in our study population is reported positively like the results reported in a study conducted in the United States [49].

In mines the main dust prevention methods include water spray, foam technology, coal seam infusion, ventilation or individual protection [50-51]. The use of dust masks is a very basic and important source of dust protection, especially when workers mine coal 
manually [52]. But during this study area all the mines lacked any precautionary measures to suppress, remove or collect dust to avoid exposure. Only six workers reported covering their face frequently with loose clothe during their work shift. The rest stated that they do not use any dust masks or any other protective measure to reduce their exposure to dust. Our findings are similar with the results of a study in which only $10 \%$ workers were observed using dust masks [53].

\section{Conclusions}

A high concentration of dust in underground coal mines is dangerous for workers' respiratory health. The traditional trend of work and profit-oriented management do not strive to improve workplace environments. Reporting from the questionnaire (IUALTD) and results of personal breathing zone samplers underscore the level of dust exposure and its consequences on health. However, no dust sample showed silica content $>5 \%$, and this is satisfactory. The number of workers with tuberculosis was large while the number of workers with asthma was small. But it is astonishing to know that most of the workers were not getting regular medical treatment. The use of a strong ventilation system, and precautionary measures (dust mask, water spray and forced ventilation) to control workers' exposure to dust can be an effective way to minimize health hazards of coal production, as well as increasing in duration the daily, weekly and annual breaks in order to reduce workers' time of exposure.

\section{Acknowledgements}

The authors are highly indebted to faculty members and laboratory staff of the College of Earth and Environmental Studies for their support and cooperation during this research work. Moreover, they are also grateful to the Mines and Minerals Department of Punjab Pakistan for allocation of access to labor and concerned officials of coal mines.

\section{Conflict of Interest}

The authors declare no conflict of interest with this research

\section{References}

1. AN F., YUAN Y., CHEN X., LI Z., LI L. Expansion energy of coal gas for the initiation of coal and gas outbursts. Fuel, 235, 551, 2019.

2. BHATTACHARYA M., PARAMATI S.R., OZTURK I., BHATTACHARYA S. The effect of renewable energy consumption on economic growth: Evidence from top 38 countries. Appl. Energy, 162, 733, 2016.
3. BAKHTAVAR E., SHAHRIAR K., ORAEE K. Transition from open-pit to underground as a new optimization challenge in mining engineering. J. Mining Sci. 45 (5), 485, 2009.

4. GLASS D., COHEN R., ROBERTS M., ALMBERG K., HOY R., GO L., SIM M. Review of the respiratory component of the queensland coal mine workers' health scheme: BMJ Publishing Group Ltd, 1497, 2018.

5. SHI X., XI T. Race to safety: Political competition, neighborhood effects, and coal mine deaths in China. J. Dev. Econ. 131, 79, 2018.

6. WANG H., NIE W., CHENG W., LIU Q., JIN H. Effects of air volume ratio parameters on air curtain dust suppression in a rock tunnel's fully-mechanized working face. Adv. Powder Technol. 29 (2), 230, 2018.

7. RODRIGUEZ-FERNANDEZ R., RAHAJENG E., VILIANI F., KUSHADIWIJAYA H., AMIYA R.M., BANGS, M.J. Non-communicable disease risk factor patterns among mining industry workers in Papua, Indonesia: longitudinal findings from the Cardiovascular Outcomes in a Papuan Population and Estimation of Risk (COPPER). Study. Occup Environ Med. 72 (10), 728, 2015.

8. JOHANN-ESSEX V., KELES C., REZAEE M., SCAGGSWITTE M., SARVER E. Respirable coal mine dust characteristics in samples collected in central and northern Appalachia. Int. J. Coal Geol. 182, 85, 2017.

9. MORENO T., TRECHERA P., QUEROL X., LAH R., JOHNSON D., WRANA A., WILLIAMSON B. Trace element fractionation between PM10 and PM2. 5 in coal mine dust: Implications for occupational respiratory health. Int. J. Coal Geol. 203 (2), 52, 2019.

10. BLACKLEY D.J., REYNOLDS L.E., SHORT C., CARSON R., STOREY E., HALLDIN C.N., LANEY A.S. Progressive massive fibrosis in coal miners from 3 clinics in Virginia. JAMA, 319 (5), 500, 2018.

11. BAUR X., HEGER M., BOHLE R., HERING K., HOFMANN-PREIß K., NOWAK D., KRAUS T. Guideline (S2k, AWMF) of the deutsche gesellschaft für pneumologie und beatmungsmedizin and the deutsche gesellschaft für arbeitsmedizin und umweltmedizin" Diagnostics and Expert Opinion in the Occupational Disease No. 4101 Silicosis (Including Coal Worker's Pneumoconiosis)". Pneumologie (Stuttgart, Germany), 70 (12), 782, 2016.

12. BEER C., KOLSTAD H.A., SØNDERGAARD K., BENDSTRUP E., HEEDERIK D., OLSEN K.E., SCHLÜNSSEN V.A systematic review of occupational exposure to coal dust and the risk of interstitial lung diseases. Eur. Clin. Respir. J., 4 (1), 1264711, 2017. doi: 10.1080/20018525.2017.1264711.

13. JI Y., REN T., WYNNE P., WAN Z., MA Z., WANG Z. A comparative study of dust control practices in Chinese and Australian longwall coal mines. Int. J. Mining Sci. Technol. 26 (2), 199, 2016. doi: https://doi.org/10.1016/j. ijmst.2015.12.004.

14. HAN B., LIU H., ZHAI G., WANG Q., LIANG J., ZHANG M., CHEN J. Estimated economic costs of coal workers' pneumoconiosis among coal workers redeployed from the Fuxin mining group in China. J. Public Health Policy, 39 (1), 57, 2018.

15. On Earth D. National Academies of Sciences E., Medicine. Mandatory airborne dust standards for us underground coal mines monitoring and sampling approaches to assess underground coal mine dust exposures: National Academies Press (US), 2018.

16. DESHMUKH A.A., KULKARNI N.P., DHATRAK S.V., NANDI S.S. Assessment of occupational dust and silica 
exposure in indian stone mining and crushing unit-a case study. Current World Environ. 12 (3), 663, 2017.

17. EGWUONWU A.V., GOEBEL M., OBI P.C. Field Evaluation of Task Requirements of Mining Jobs in Nigerian Quarry Mines: A Pilot Study. Paper presented at the International Conference on Applied Human Factors and Ergonomics, 2018.

18. MESHI E., KISHINHI S., MAMUYA S., RUSIBAMAYILA M. Thermal exposure and heat illness symptoms among workers in Mara gold mine, Tanzania. Ann. Glob. Health, 84 (3), 2018.

19. CLIFF D., LABRANCHE N., SHEPHERD M., DJUKIC F. Improving respirable coal dust exposure monitoring and control, Proceedings of the 18th Coal Operators' Conference, Mining Engineering, University of Wollongong, 300, 2018.

20. MAJUMDER P., PALIT D. Microbial diversity of soil in some coal mine generated wasteland of Raniganj Coalfield, West Bengal, India. Int. J. Current Microbiol. Appl. Sci. 5 (2), 637, 2016.

21. STACEY P., THORPE A., ROBERTS P., BUTLER O. Determination of respirable-sized crystalline silica in different ambient environments in the United Kingdom with a mobile high flow rate sampler utilising porous foams to achieve the required particle size selection. Atmos. Environ. 182, 51, 2018.

22. ARRANDALE V., KALENGE S., DEMERS P. Silica exposure in a mining exploration operation. Arch. Environ. Occup. Health, 73 (6), 351, 2018.

23. QIAN J., LIU Z., LIN S., LI X., HONG S., LI D. Characteristics analysis of post-explosion coal dust samples by x-ray diffraction. Combust. Sci. Technol. 190 (4), 740, 2018.

24. LEON-KABAMBA N., NGATU N.R., KAKOMA S.J.B., NYEMBO C., MBELAMBELA E.P., MORIBE R.J., OSCAR-LUBOYA N. Respiratory health of dust-exposed Congolese coltan miners. Int. Arch. Occup. Environ. Health, 91 (7), 859, 2018.

25. HOSSAIN M.I., PARVEZ M., ZOHORA F.T., ISLAM M.S., BARI L. Prevalence of asthmatic respiratory complications among the rural community of Tangail area in Bangladesh. Int. J. Community Med. Public Health, 5 (4), 1291, 2018.

26. HAN F., CHEN Y., WU B., KANG N., ZHANG S. Occupational health risk assessment of coal dust in coal industry chain. Zhonghua lao dong wei sheng zhi ye bing za $\mathrm{zhi}=$ Zhonghua laodong weisheng zhiyebing zazhi= Chin J. Ind. Hyg. Occup. Diseas, 36 (4), 291, 2018.

27. LEECH, N.L., BARRETT K.C., MORGAN.G.A. IBM SPSS for Intermediate Statistics. Use and Interpretation, Fifth Edition, New York. 382, 2014.

28. ALI H.M.Z., ZAHOOR A., AFZAL H.M.Z., YASIN M. Characterisation of Patala formation coal reserves of salt range and its application. Pak. J. Sci Ind. Res. A: Physical Sciences, 61 (2), 96, 2018.

29. TONG R., CHENG M., YANG X., YANG Y., SHI, M. Exposure levels and health damage assessment of dust in a coal mine of Shanxi Province, China. Process Safe. Environ. Protec. 128, 184, 2019.

30. PERRET J.L., PLUSH B., LACHAPELLE P., HINKS T.S., WALTER C., CLARKE P., STEWART A. (2017). Coal mine dust lung disease in the modern era. Respirology, 22 (4), 662, 2017.

31. MANDRIOLI D., SCHLÜNSSEN V., ADAM B., COHEN R.A., COLOSIO C., CHEN, W., IVANOV I.D. WHO/ILO work-related burden of disease and injury: protocol for systematic reviews of occupational exposure to dusts and/ or fibres and of the effect of occupational exposure to dusts and/or fibres on pneumoconiosis. Environ. Int. 119, 174, 2018.

32. RAJU A.E., JHANSI .K, AMRUTA K., RASOOLSAYAAD K., MUNISEKHAR. A study on pulmonary function tests in coal mine workers in khammam district, Telangana-India. Int. J. Physiother. Res. 2 (3), 502, 2014.

33. MIYABAYASHI I., WASHIO M., YANAGIMOTO T., FORTIN E., YASUMURA S. Population aging and health of older people in japan: introduction of health issues and care system for the elderly health issues and care system for the elderly (pp. 1-16): Springer, 2019.

34. RUDOLPH C.W., MARCUS J., ZACHER H., RUDOLPH C.W., MARCUS J., MAH R., ZACHER H. Global issues in work, aging and retirement aging and work in the $21^{\text {st }}$ century (pp. 292-324): Routledge, 2018.

35. LIU Y., PLEASANTS R.A., CROFT J.B., LUGOGO N., OHAR J., HEIDARI K., KRAFT, M. Body mass index, respiratory conditions, asthma, and chronic obstructive pulmonary disease. Respir. Med., 109 (7), 851, 2015.

36. KUMARI-PRASAD S., SINGH S., BOSE A., PRASAD B., BANERJEE O., BHATTACHARJEE A., MUKHERJEE S. Combined effect of coal dust exposure and smoking on the prevalence of respiratory impairment among coal miners of West Bengal, India. Arch. Environ. Occup. Health,1 1, 2019.

37. OSHA 29 CFR 1910.146, Permit required confined spaces; OSHA 29 CFR 1926 Subpart AA, Confined spaces in construction; Governor's Executive Order 2000-92.

38. SUN B., CHENG W., WANG J., WANG H. Effects of turbulent airflow from coal cutting on pollution characteristics of coal dust in fully-mechanized mining face: A case study. J. Clean. Prod. 201, 308, 2018.

39. MAYALA L.P., VEIGA M.M., KHORZOUGHI M.B. Assessment of mine ventilation systems and air pollution impacts on artisanal tanzanite miners at Merelani, Tanzania. J. Clean. Prod. 116, 118, 2016.

40. ROBERTSON B. A review of ventilation and gas management in underground mines. AusIMM Bulletin 72 , 2017.

41. WANG Y., LUO G., GENG F., LI Y., LI Y. Numerical study on dust movement and dust distribution for hybrid ventilation system in a laneway of coal mine. J. Loss Prevent Proc. 36, 146, 2015.

42. CAI P., NIE W., CHEN D., YANG S., LIU Z. Effect of air flowrate on pollutant dispersion pattern of coal dust particles at fully mechanized mining face based on numerical simulation. Fuel, 239, 623, 2019.

43. YUEZE L., AKHTAR S., SASMITO A.P., KURNIA J.C. Prediction of air flow, methane, and coal dust dispersion in a room and pillar mining face. Int. J. Mining Sci Technol. 27 (4), 657, 2017.

44. LIU Q., NIE W., HUA Y., PENG H., LIU Z. The effects of the installation position of a multi-radial swirling aircurtain generator on dust diffusion and pollution rules in a fully-mechanized excavation face: a case study. Powder technol. 329, 371, 2018.

45. GOLDSMITH, D.F. What is the global impact of the new (2016) osha silica dust standard? : BMJ Publishing Group Ltd, 1212, 2018.

46. BATOOL A.I., ARSHAD M., REHMAN M.F.U., NAVEED N.H., INAYAT I., NOREEN A., KHANUM A. Study of tuberculosis associated workplace risk factors among coal miners, J. Entomol. Zool. Stud. 5 (1), 609, 2017. 
47. HAN F., WANG D., JIANG J., ZHU X. A new design of foam spray nozzle used for precise dust control in underground coal mines. Int. J. Mining Sci. Technol. 26 (2), 241, 2016.

48. GO L.H., KREFFT S.D., COHEN R.A., ROSE, C.S. Lung disease and coal mining: what pulmonologists need to know. Curr. Opin. Pulm. Med. 22 (2), 170, 2016.

49. SCHMAJUK G., TRUPIN L., YELIN E., BLANC P.D. Prevalence of arthritis and rheumatoid arthritis in coal mining counties of the US. Arthritis Care Res. 71 (9), 1209, 2019. doi: $10.1002 / a c r .23874$.

50. ZHOU G., ZHANG Q., BAI R., FAN T., WANG G. The diffusion behavior law of respirable dust at fully mechanized caving face in coal mine: CFD numerical simulation and engineering application. Process Saf. Environ. Protection, 106, 117, 2017.

51. FAN T., ZHOU G., WANG J. Preparation and characterization of a wetting-agglomeration-based hybrid coal dust suppressant. Process Saf. Environ. Protection, 113, 282, 2018.

52. WANG H., WANG C., WANG D. The influence of forced ventilation airflow on water spray for dust suppression on heading face in underground coal mine. Powder Technol. 320, 498, 2017.

53. YADAV A.K., JAMAL A. Suspended particulate matter and its management system surrounding opencast coal mines. Environ. Quality Managem. 28 (2), 123, 2018. 